\title{
A DEVICE IN THE TEACHING OF TOPOGRAPHIC MAPS.
}

\author{
By Wilitam Harmon Norton, \\ Cornell College, Iowa.
}

Teachers of laboratory physiography may be interested in a little device designed to meet some initial difficulties in the use of topographic maps. We perhaps expect the beginner to give us a written description of the area studied-a translation into passable English from the foreign language of contours and other conventional signs. But his topographic vocabulary is limited, he has no pattern or model for his work, and though he may be guided by questions, his attitude is apt to be very like that of the Children of Israel in the strawless brick-yards of Egypt.

As a help to the first stumbling steps I have been using a device suggested by that form of the examination question-which is not a question at all but a declarative sentence with some words or phrases left to be filled in by the pupil-a form which is certainly a time saver for pupil and teacher, whateyer its demerits may be. Our beginners in the physiographic laboratory of Cornell College, in their first few map studies, are furnished with descriptions of the areas, printed on their note-book paper -descriptions with many blanks to be filled in from their investigations of the maps. This serves as an outline and question-set and somewhat as a pattern for their later work on other quadrangles. It also enables the teacher to introduce easily valuable material not discoverable from the map, if he considers it good pedagogy to do so. By concentrating the attention, and by relieving from mechanical pen work, the device saves at least twenty-five per cent of the pupils' time.

An example, somewhat abridged, will illustrate the merits and demerits of the plan. The blanks have been filled in italics with such words and phrases as the pupil can supply, or with such as may be suggested in the class discussion.

\section{Portagr Quadrangle.}

The Portage quadrangle lies in the south central part of Wisconsin. The lowest points are found where the Wisconsin, the Fox and the Grand rivers leave the quadrangle at an elevation of about 780 feet above sea level. The highest point is Observatory Hill, IIOO feet A. T. The maximum relief is thus 320 feet.

DRAINAGE. The prevalence of lakes and swamps marks a sluggish, and impeded and undeveloped drainage. The proportion of undrained land reaches 37 per cent of the total area. ${ }^{1}$ The longest continuous belt of marsh is that through which the Fox river takes its way, extending from Pardeeville in the southeastern township to the northwestern corner of the quadrangle. In the distance of 23 miles the marsh descends little more than 20 feet. In width it varies from a quarter of a mile to one and one-half and two miles. Tributary marshes join this axial mash; that of Spring Brook is 9 miles long and that of Neenah Creek is two and one-half miles in width. These numerous marshes so connect as to enclose insular areas of upland, as is seen in almost every township.

In the marsh lands are found numerous lakes connected by creeks with the rivers. The largest lakes of the area are formed by expansions of the Fox river. They are elongate in shape, and the largest, Buffalo Lake, reaches a length of five miles. They occupy depressions as yet unfilled by silt and vegetation and their depth is evidently shallow.

The course of the Fox river has already been described by the de-

1 Easily found by having one of the class weigh the map (trimmed) and then cut out and weigh the lake and marsh areas. 
scription of the marshy belt through which it flows. Grand River, a tributary of the Fox, crosses the northeastern section of the quadrangle with inosculating channels. Wisconsin river and its tributary, Baraboo river, flow in a southeasterly direction across the southziestern portion of the area.

The Wisconsin and the Grand, as well as the Fox river, flow through wide belts of marsh land. The marshes of the three rivers are not separated by upland divides, but coalesce in a continutous swamp. If this were slightly inundated it could be traversed by a boat from the northeastern corner of the area to the northwestern and thence to the southwestern corner. Every township of the quadrangle could then be visited.

At high water the Wisconsin now discharges some of its flood waters into the Fox river.

The Fox and the Wisconsin rivers have scarcely begun to excavate valleys below the level of the marsh lands through which they take their ways. When they actively begin the work of erosion it is improbable that the two streams will deepen their valleys at Portage at the same rate. If the channel of the larger river, the $W$ isconsin, is more rapidly deepened than that of the Fox river, the following consequences will ensue: Gullies working back by head erosion from the Wisconsin at Portage will reach the channel of the Fox river and capture its headwaters. The divide between the two rivers will thus be shifted to the marsh lands of the Fox river valley north of Portage.

The UPLANDS. From the level of the marsh lands, which are found in every township, rise aplands whose lower portions are formed of glacial drift and whose higher knobs and detached ridges are, for the most part, the erosion remnants of ancient horizontal strata which once extended over the entire area. The bases of the knobs are elliptical in shape; the direction of their long axes is various; their sides are steep. The highest rises 200 feet above the gentle slopes about its base.

The relief of the quadrangle is due to unequal erosion in a former cycle, and to unequal deposit of glacial drift which marked the beginning of. the present cycle. The Wisconsin ice sheet moved from east-north-east over the area, and its terminal moraine is situated but a few miles to the west. The area is in the stage of topographic infancy. This is shown by the wide marshes yet undrained, the numerous lakes not yet effaced, the low swampy divides between the rivers, and by the fact that the rivers and creeks have scarcely begun their work of valley excavation.

CULTURE. The marshes of the area seriously lessen its value for agricultural purposes.

Some of the swamps may have an economic value because of the deposits of peat which may be supposed to underlie them. For plow land the sides of the knobs and ridges have least value, because of their steep slope. The most valuable agricultural land at present as shown by the density of poptulation is that of the gently sloping uplands.

The city of Portage takes its name and derives its advantage of situation from the portage between Wisconsin and Fox rivers. The Fox and Wisconsin rivers are here connected by canal, so that it is possible for a small boat to pass from Lake Michigan to the Mississippi river.

$U_{p}$ the Fox river, with its border of wild rice swamps, came in June, 1673, two birch-bark canoes bearing the famous French explorers, Joliet and Marquette, on their way from Quebec to the unknown West. Crossing the portage of our map they embarked on the Wisconsin, and a few days later swung out upon the broad Mississippi nearly opposite the site of McGregor, Iowa. 